\title{
PERADILAN SATU ATAP SEBAGAI PERWUJUDAN KEKUASAAN KEHAKIMAN YANG MERDEKA
}

\author{
Umi Supraptiningsih \\ (Dosen Tetap Jurusan Syari'ah STAIN Pamekasan dan peserta Program Doktor \\ Ilmu Hukum Untag Surabaya)
}

\begin{abstract}
Abstrak:
Pasal 1 UU No. 4 Tahun 2004 menyatakan bahwa "kekuasaan Kehakiman adalah kekuasaan Negara yang merdeka untuk menyelenggarakan peradilan guna menegakkan hukum dan keadilan berdasarkan Pancasila demi terselenggaranya Negara Hukum Republik Indonesia". Maksud dari kekuasaan kehakiman yang merdeka adalah kekuasaan kehakiman yang tidak dicampuri oleh kekuasaan eksekutif atau kekuasaan ekstrayudisial dalam melaksanakan fungsi peradilan. Untuk menciptakan kekuasaan kehakiman dalam posisi "independen" tersebut, maka harus ada korelasi antara fungsi yudikatif/peradilan dan proses demokrasi, dimana pembentukan dan jaminan independensi atau kebebasan kekuasaan kehakiman seharusnya diciptakan secara aktif oleh semua sarjana hukum, polisi, kejaksaan dan penegak hukum lainnya. Dengan mewujudkan sistem satu atap (one roof system) diharapkan apa yang menjadi cita-cita hukum (rechtsidee) untuk mewujudkan kekuasaan kehakiman yang merdeka (independent) dalam rangka penegakan hukum dan keadilan demi terselenggaranya Negara Hukum Republik Indonesia.
\end{abstract}

Kata Kunci:

peradilan satu atap, kekuasaan kehakiman yang merdeka, dan lembaga peradilan

\section{Pendahuluan}

Dalam Undang-Undang Dasar 1945 dinyatakan bahwa negara Indonesia adalah negara hukum ${ }^{\mathbf{1}}$ (rechstaat), bukan negara kekuasaan (machstaat). Ini berarti bahwa kedaulatan atau kekuasaan tertinggi dalam negara tidak didasarkan kepada kekuatan kekuasaan semata,

\footnotetext{
${ }^{1}$ Bunyi Pasal 1 ayat (3) UUD 1945 (perubahan ketiga)
} 
tetapi didasarkan kepada hukum, dalam arti cita hukum (rechtsidee) yang di dalamnya mengandung cita-cita luhur bangsa Indonesia.

Dengan demikian, hukum mempunyai kedudukan yang tinggi dalam negara. Di Negara Republik Indonesia hukum bersumber pada Pancasila. Pada jaman Orde Lama pernah disebut sebagai alat, yaitu alat revolusi. Apabila alat di sini dalam pengertian pengabdian, dan revolusi dalam pengertian cita-cita dan tujuan bangsa Indonesia seperti yang tercantum dan terkandung dalam Pembukaan UUD Tahun 1945, masih dapat dimengerti. Tetapi kalau hukum dipergunakan sebagai alat menghalalkan segala cara dalam mencapai tujuan (het doel heiligtde middelen) adalah tidak dapat diterima.

Dalam Seminar Hukum Nasional I tahun 1963 yang berhubungan dengan pembinaan hukum nasional (Lembaga Pembinaan Hukum Nasional) dinyatakan bahwa hukum nasional berfungsi "pengayoman". Prinsip ini, hukum berfungsi sebagai pengayoman, dapatlah kita terima hingga sekarang, karena fungsi hukum yang mengatur hubungan kehidupan manusia dalam masyarakat mempunyai tujuan pula untuk melindungi kepentingankepentingan.

Hukum yang adil di Indonesia adalah hukum yang bersumber kepada kepribadian dan falsafah hidup bangsa Indonesia yang mencerminkan rasa keadilan bangsa Indonesia, mampu melindungi kepentingan-kepentingan material dan spiritual, dan mampu melindungi kepribadian dan kesatuan bangsa, kelangsungan hidup bangsa dan negara serta mengejar cita-cita nasional. ${ }^{2}$

Tujuan hukum sebagaimana diketengahkan di muka adalah menghendaki adanya keseimbangan kepentingan, ketertiban, keadilan, ketenteraman, dan kebahagiaan setiap manusia, maka dapat diketahui apa sebenarnya fungsi hukum itu. Dengan mengingat tujuan hukum, maka dapat dirinci secara garis besar, fungsi hukum sebagai berikut :

\footnotetext{
2 Darji Darmodiharjo, Sumber Dari Segala Sumber Hukum di Indonesia, (Malang: Pidato Pengukuhan Guru Besar Luar Biasa dalam mata kuliah Filsafat Hukum pada Fakultas Hukum dan Pengetahuan Masyarakat Universitas Brawijaya, 1976), tidak diterbitkan.
} 
a. Hukum berfungsi sebagai alat ketertiban dan keteraturan masyarakat. Fungsi ini memungkinkan untuk diperankan oleh hakim karena hukum memberikan petunjuk kepada masyarakat bagaimana mereka harus bertingkah laku, dalam arti mana yang diperbolehkan oleh hukum dan mana yang dilarang olehnya sehingga setiap anggota masyarakat mengetahui apa yang menjadi hak dan kewajibannya. Kalau mereka menyadari dan melaksanakan perintah maupun menghindari larangan yang tercantum dalam hukum, kita yakin bahwa fungsi hukum sebagai alat ketertiban masyarakat dapat direalisasikan.

b. Hukum berfungsi sebagai sarana untuk mewujudkan keadilan sosial lahir dan batin. Hukum yang bersifat mengikat dan memaksa serta dapat dipaksakan oleh alat negara yang berwenang mempunyai pengaruh besar terhadap orang yang akan melakukan pelanggaran sehingga mereka takut akan ancaman hukumannya. Hukum yang bersifat memaksa dapat diterapkan kepada siapa pun yang bersalah. Mereka yang melakukan kesalahan mungkin dihukum penjara, didenda, diminta membayar ganti rugi, atau disuruh membayar hutangnya, maka dengan demikian keadilan dicapai.

c. Hukum berfungsi sebagai alat penggerak pembangunan karena ia, yang mempunyai daya mengikat dan memaksa, dapat dimanfaatkan sebagai alat otoritas untuk mengarahkan masyarakat ke arah yang lebih maju. Fungsi yang demikian adalah fungsi hukum sebagai alat penggerak pembangunan.

d. Hukum berfungsi sebagai alat kritik (fungsi kritis). Fungsi ini berarti bahwa hukum tidak hanya mengawasi masyarakat semata-mata, tetapi berperan juga mengawasi para pejabat pemerintah, para penegak hukum, mau pun aparatur pengawasan sendiri. Dengan demikian, semuanya harus bertingkah laku menurut ketentuan yang berlaku. Jika demikian halnya maka ketertiban, kedamaian, dan keadilan dalam masyarakat dapat diwujudkan dan fungsi kritis hukum dapat berjalan baik.

e. Hukum berfungsi sebagai sarana untuk menyelesaikan pertikaian. ${ }^{3}$

3 Daliyo, Pengantar Ilmu Hukum (Buku Panduan Mahasiswa) (Jakarta: Prenhallindo, 2001), hlm. 40-41. 
Dengan demikian, hukum mempunyai peranan yang sangat besar dalam pergaulan hidup di tengah-tengah masyarakat. Sehingga hukum dan masyarakat bagaikan dua sisi mata uang (ibi ius ubi societas), yakni di mana ada masyarakat maka di sana ada hukum. Hukum terbentuk karena adanya komunitas manusia yang disebut masyarakat, dan merupakan salah satu sarana pembaruan dan pembangunan masyarakat (law as a tool of social engineering) ${ }^{4}$. Peranan hukum yang besar itu dapat kita lihat dari ketertiban, ketentraman, dan tidak terjadinya ketegangan di dalan masyarakat, karena hukum mengatur, menentukan hak dan kewajiban serta melindungi kepentingan individu dan kepentingan sosial. Dalam konteks pergaulan hidup para individu, hukum berperan sedemikian rupa sehingga sesuatu yang berkaitan dengan hubungan antara individu yang satu dengan yang lain berjalan dengan tertib dan teratur, karena hukum secara tegas menentukan hak dan kewajiban mereka masingmasing. Yang ada kaitannya dengan pemerintah pun berjalan mulus karena masing-masing individu mengetahui apa yang menjadi hak dan kewajibannya. Jadi hukum harus mampu mewujudkan tentang keadilan, kegunaannya bagi kepentingan sosial, dan kepastian hukum yang umum sifatnya. ${ }^{5}$

Namun pada kenyataannya, dalam kehidupan bermasyarakat, karena memang pada kenyataannya menurut Aristoteles manusia itu adalah zoon politicon artinya bahwa manusia itu sebagai makhluk pada dasarnya selalu ingin bergaul dan berkumpul dengan sesama manusia lainnya, jadi makhluk yang suka bermasyarakat. Dan oleh karena sifatnya yang suka bergaul satu sama lain, maka manusia disebut makhluk sosial ${ }^{6}$. Dalam pergaulan tersebut tentunya akan terjadi beberapa masalah baik itu dilakukan secara sengaja mau pun tidak. Permasalahan tersebut harus dapat diselesaikan secara adil dan bijaksana, sehingga diperlukanlah suatu lembaga yang bersifat merdeka (independent). Satu-satunya lembaga yudikatif yang berpuncak di Mahkamah Agung merupakan dambaan seluruh warga negara Indonesia yang dapat memberikan penyelesaian hukum yang

${ }^{4}$ H. Muchsin, Ikhtisar Hukum Indonesia (Jakarta: Iblam, 2005), hlm. 15

5 Ibid., hlm. 105

6 CST. Kansil, Pengantar Ilmu Hukum dan Tata Hukum Indonesia (Jakarta: PN. Balai Pustaka, 1984), hlm. 29. 
obyektif tanpa harus dan dapat dipengaruhi oleh badan atau pun lembaga-lembaga lainnya.

Berbagai upaya telah dilakukan untuk menjaga dan mempertahankan suatu lembaga yang merdeka (independent) tanpa ada pihak atau badan lain yang dapat memengaruhi terhadap lembaga yudikatif, mulai dari berbagai peraturan sampai pada rekrutment para hakim dari lembaga peradilan tersebut, yang pada akhirnya membentuk lembaga-lembaga peradilan tersebut berada pada sistem satu atap (one roof system). Namun selanjutnya yang menjadi suatu pertanyaan besar adalah apakah dengan sistem satu atap tersebut sudah dapat memberikan jaminan bahwa kekuasaan kehakiman betul-betul merdeka? Atau tidak adakah badan lain yang dapat turut campur (intervensi) dalam persoalan peradilan?

\section{Tinjauan Historis Peraturan Perundangan Kehakiman}

Kekuasaan kehakiman merupakan salah satu amanah dari Undang-Undang Dasar Tahun 1945, terutama pasal 24 dan 25, yang harus dijalankan. Bab IX pasal 24 undang-undang tersebut menyatakan: (1) Kekuasaan kehakiman merupakan kekuasaan yang merdeka untuk menyelenggarakan peradilan guna menegakkan hukum dan keadilan (perubahan ketiga); (2) Kekuasaan kehakiman dilakukan oleh sebuah Mahkamah Agung dan badan peradilan yang berada diwilayahnya dalam lingkungan peradilan umum, lingkungan peradilan agama, lingkungan peradilan militer, lingkungan peradilan tata usaha negara dan oleh sebuah Mahkamah Konstitusi (perubahan ketiga); (3) Badan-badan lain yang fungsinya berkaitan dengan kekuasaan kehakiman diatur dalam Undang-undang (perubahan keempat). Sedangkan dalam pasal 25 dinyatakan bahwa syarat-syarat untuk menjadi dan untuk diberhentikan sebagai hakim ditetapkan dengan Undang-Undang (asli)

Apa yang menjadi amanat dari kedua pasal tersebut juga harus tercermin dan diindahkan dalam peraturan yang mengatur tentang kekuasaan kehakiman. Dari peraturan yang satu (pertama) ke peraturan berikutnya terdapat suatu kemajuan menuju terwujudnya suatu peradilan yang merdeka.

Pada jaman Orde Baru telah ditetapkan dua undang-undang yang menjadi dasar dari kekuasaan kehakiman pada saat itu yaitu: (1) Undang-undang No. 19 Tahun 1964 (LN. 1964 No. 17) tentang 
Ketentuan-ketentuan Pokok Kekuasaan Kehakiman, dan (2) Undangundang No. 13 Tahun 1965 tentang Pengadilan dalam Lingkungan Peradilan Umum dan Mahkamah Agung. Kedua Undang-undang ini memberi peluang yang sangat besar kepada Presiden selaku Pimpinan Besar Revolusi (PBR) untuk turut campur tangan dalam urusan pengadilan. Bahkan dalam penjelasan UU No. 19 Tahun 1964 secara tegas-tegas menyebutkan pengadilan selaku alat revolusi adalah tidak bebas dari kekuasaan pemerintah 7 .

Ketentuan Pasal 19 UU No. 19 Tahun 1964 menyebutkan: "Demi kepentingan revolusi, kehormatan negara dan bangsa atau kepentingan masyarakat mendesak presiden dapat turun atau campur tangan dalam soal-soal pengadilan". Pasal tersebut jelas bertentangan dengan asas kemandirian hakim dan bertentangan pula dengan amanat pasal 24 dan 25 UUD 1945.

Selanjutnya keluarlah UU No. 14 Tahun 1970 (LN. 1970 No. 74) tentang Ketentuan-ketentuan Pokok Kekuasaan Kehakiman yang telah mencabut dan menggantikan keberadaan UU No. 19 Tahun 1964. Dalam UU ini kemerdekaan kekuasaan kehakiman dijamin lebih baik dari pada peraturan sebelumnya. Hal ini tercermin dari bunyi pasal 1 UU tersebut bahwa kekuasaan kehakiman adalah kekuasaan negara yang merdeka untuk menyelenggarakan peradilan guna menegakkan hukum dan keadilan berdasarkan Pancasila demi terselenggaranya Negara Hukum Republik Indonesia. Hal ini dipertegas lagi dalam ketentuan pasal 4 ayat (3) yang menyebutkan bahwa segala campur tangan dalam urusan peradilan oleh pihak lain di luar kekuasaan kehakiman dilarang, kecuali dalam hal-hal yang disebutkan dalam Undang-undang Dasar. Sedangkan penjelasan pasal 1 menyebutkan bahwa kekuasaan kehakiman yang merdeka ini mengandung pengertian di dalamnya kekuasaan kehakiman yang bebas dari campur tangan pihak kekuasaan negara lainnya, dan kebebasan dari paksaan, direktiva atau rekomendasi yang datang dari pihak ekstra judiciil, kecuali dalam hal-hal yang diijinkan oleh undangundang kebebasan dalam melaksanakan wewenang judiciil tidaklah

\footnotetext{
${ }^{7}$ H. Abdurrahman, Kekuasaan Kehakiman di Indonesia dalam Era Reformasi, Orasi ilmiah pada acara Reuni dan Dies Natalis Sekolah Tinggi Ilmu Hukum Sultan Adam (STIHSA), (Banjarmasin, 28 April 2005), hlm. 11.

8 Al. Wisnubroto, Hakim dan Peradilan di Indonesia - dalam beberapa aspek kajian (Yogyakarta: Penerbit Universitas Atma Jaya, 1997), hlm. 8.
} 
mutlak sifatnya, karena tugas dari para hakim adalah untuk menegakkan hukum dan keadilan berdasarkan Pancasila dengan jalan menafsirkan hukum dan mencari dasar-dasar serta asas-asas yang menjadi landasannya melalui perkara-perkara yang dihadapkan kepadanya sehingga keputusannya mencerminkan perasaan keadilan bangsa dan rakyat Indonesia9.

Dalam rangka melaksanakan ketentuan pasal 12, telah ditetapkan sejumlah peraturan perundang-undangan, yaitu :

1. UU No. 14 Tahun 1985 (LN Tahun 1985 No. 73) tentang Mahkamah Agung. Dengan berlakunya UU ini, maka UU No. 13 Tahun 1965 sepanjang mengenai ketentuan Mahkamah Agung dinyatakan tidak berlaku.

2. UU No. 2 Tahun 1986 (LN Tahun 1986 No. 20) tentang Peradilan Umum.

3. UU No. 5 Tahun 1986 (LN Tahun 1986 No. 77) tentang Peradilan Tata Usaha Negara.

4. UU No. 7 Tahun 1989 (LN Tahun 1989 No. 49) tentang Peradilan Agama, dengan ditetapkannya UU ini telah mencabut dan menyatakan tidak berlaku lagi :

a. Peraturan tentang Peradilan Agama di Jawa dan Madura (Stb. 1882 No. 152 Jo. Stb. 1937 No. 116 dan No. 610)

b. Peraturan tentang Kerapatan Qadi dan Kerapatan Qadi Besar untuk sebagian Residensi Kalimantan Selatan dan Timur (Stb. 1937 No. 638 dan No. 639).

c. Peraturan Pemerintah No. 45 Tahun 1957 tentang pembentukan Peradilan Agama/Mahkamah Syari'ah diluarJawa dan Madura (LN. Tahun 1957 No. 99)

5. UU No. 31 Tahun 1997 (LN Tahun 1997 No. 84) tentang Peradilan Militer.

Namun pada kenyataannya, walaupun dalam pasal 1 UU No. 14 Tahun 1970 disebutkan "kekuasaan kehakiman yang merdeka" tetapi dalam pasal 11 masih memberikan suatu dualisme kepemimpinan dalam lembaga peradilan, yang berbunyi sebagai berikut: (1) Badan-badan yang melakukan peradilan tersebut pasal 10 ayat (1) organisatoris, administratif, dan finansial ada di bawah kekuasaan masing-masing Departemen yang bersangkutan; (2)

${ }_{9}$ Ibid, hlm. 12 
Mahkamah Agung mempunyai organisasi, administrasi, dan keuangan sendiri10.

Dari pasal di atas jelaslah bahwa kemandirian dan kemerdekaan kekuasaan kehakiman belum penuh karena secara organisatoris, administratif, dan finansial ada di bawah kekuasaan masing-masing departemen yang bersangkutan, namun dalam bidang pembinaan, dan pengawasan berada di bawah Mahkamah Agung.

Selanjutnya lahirlah UU No. 35 Tahun 1999 yang merupakan perubahan dari UU No. 14 Tahun 1970. Dalam UU No. 35 Tahun 1999 merubah ketentuan pasal 11 yang menyatakan bahwa: (1) Badanbadan peradilan sebagaimana dimaksud dalam pasal 10 ayat (1) secara organisatoris, administratif dan finansial berada dibawah kekuasaan Mahkamah Agung; (2) Ketentuan mengenai organisasi, administrasi dan finansial sebagaimana dimaksud dalam ayat (1) untuk masing-masing lingkungan peradilan diatur lebih lanjut dengan undang-undang sesuai dengan kekhususan lingkungan peradilan masing-masing.

Lahirnya UU No. 35 Tahun 1999 tersebut merupakan awal reformasi kemandirian dan kemerdekaan kekuasaan kehakiman. Terakhir, dengan lahirnya UU No. 4 Tahun 2004 lebih mengatur secara jelas dan tegas kemandirian dan kemerdekaan lembaga peradilan.

Sebagaimana termaktub dalam pasal 24 ayat (2) UUD 1945 yang menyebutkan bahwa kekuasaan kehakiman dilakukan oleh Mahkamah Agung dan badan peradilan yang berada di wilayahnya dalam lingkungan peradilan umum, lingkungan peradilan agama, lingkungan peradilan militer lingkungan peradilan tata usaha negara dan oleh sebuah Mahkamah Konstitusi (perubahan ketiga).

Ada perkembangan baru di dunia kehakiman, selain Mahkamah Agung yang mempunyai kewenangan untuk menguji peraturan perundang-undangan dibawah undang-undang terhadap undang-undang, ada Mahkamah Konstitusi yang juga diberi kewenangan untuk menguji undang-undang terhadap Undangundang Dasar.

10 K. Wantjik Saleh, Kehakiman dan Peradilan (Jakarta: Ghalia Indonesia, 1977), hlm. 195-196. 
Mahkamah Konstitusi sebagai lembaga negara yang baru dilingkungan kehakiman diatur berdasarkan Undang-Undang Nomor 24 Tahun 2003. Susunan Mahkamah Konstitusi mempunyai 9 (sembilan) orang anggota hakim konstitusi yang ditetapkan dengan Keputusan Presiden, dengan komposisi seorang Ketua merangkap anggota, seorang Wakil Ketua merangkap anggota dan 7 (tujuh) orang hakim konstitusi (pasal 4).

Mahkamah Konstitusi berwenang mengadili pada tingkat pertama dan terakhir yang putusannya bersifat final untuk: (1) Menguji undang-undang terhadap Undang-Undang Dasar Negara Republik Indonesia Tahun 1945; (2) memutuskan sengketa kewenangan lembaga negara yang kewenangannya diberikan oleh undang-undang Dasar Negara Republik Indonesia Tahun 1945; (3) memutus pembubaran partai politik; dan (4) memutus perselisihan tentang hasil pemilihan umum (pasal 10).

Selain kedua badan kekuasaan kehakiman tersebut sebagai amanat dari UUD Tahun 1945 juga dibentuk lembaga baru yaitu Komisi Yudisial yang bersifat mandiri dan mempunyai kewenangan mengusulkaan pengangkatan hakim agung dan mempunyai wewenang lain dalam rangka menjaga dan menegakkan kehormatan, keluhuran martabat serta perilaku hakim (pasal 24B ayat 1 UUD 1945 perubahan ketiga). Selanjutnya keluar UU No. 22 Tahun 2004 tentang Komisi Yudisial, yang secara khuisus mengatur tentang tugas, wewenang, dan struktur KY. Keberadaan Komisi Yudisial dibentuk tersendiri di luar Mahkamah Agung, maka subyek yang diawasinya dapat diperluas ke semua hakim termasuk hakim konstitusi dan hakim di seluruh Indonesia. Di samping itu, kedudukan Komisi Yudisial itu dapat pula diharapkan bersifat mandiri dan independen.

\section{Deskripsi Peradilan Satu Atap (One Roof System)}

Pemahaman peradilan satu atap (one roof system) dimaksudkan bahwa keempat lembaga peradilan negara di Indonesia yaitu Peradilan Umum, Peradilan Agama, Peradilan Militer, dan Peradilan Tata Usaha Negara berpuncak pada Mahkamah Agung. Sebagaimana yang telah diamanatkan dalam pasal 10 UU No. 4 Tahun 2004, bahwa: (1) Kekuasaan Kehakiman dilakukan oleh sebuah Mahkamah Agung dan badan peradilan yang berada di bawahnya serta oleh sebuah Mahkamah Konstitusi; (2) Badan peradilan yang berada di bawah 
Mahkamah Agung meliputi badan peradilan dalam lingkungan Peradilan Umum, Peradilan Agama, Peradilan Militer, dan Peradilan Tata Usaha Negara. Sedangkan pasal 11 ayat (1) UU No. 4 Tahun 2004, menyebutkan bahwa: "Mahkamah Agung merupakan pengadilan negara tertinggi dari keempat lingkungan peradilan sebagaimana dimaksud dalam pasal 10 ayat (2)."

Dalam segala hal, baik dalam urusan peradilan (perkara) maupun dalam urusan administrasi, organisasi, dan finansial (keuangan), menjadi kewenangan Mahkamah Agung untuk mengaturnya. Hal ini dipertegas dalam pasal 13 ayat (1) UU No. 4 Tahun 2004 yang menyebutkan bahwa: "Organisasi, administrasi dan finansial Mahkamah Agung dan badan peradilan yang berada di bawahnya berada di bawah kekuasaan Mahkamah Agung."

Tujuan yang terkandung dalam beberapa pasal di atas, dalam rangka mewujudkan kekuasaan kehakiman yang merdeka (independen). Dengan satu kontrol dari suatu lembaga dan tanpa ada kontrol dari lembaga lain di luar lembaga peradilan (ekstrayudisial) diharapkan kekuasaan kehakiman dapat secara bebas dan merdeka dalam melakukan penerapan kekuasaannya. Sehingga dengan berpuncak di Mahkamah Agung dalam segala urusan, maka lembaga peradilan tersebut tidak ada lagi ketergantungan dengan lembaga atau instansi lain di luar lembaga peradilan.

Fenomena yang telah diajarkan oleh Montesquieu mengenai ajaran pemisahan kekuasaan yang menjadikan inspirasi atas peradilan satu atap (one roof system) dalam lembaga peradilan. Dengan berintikan pada independensi masing-masing alat kelengkapan negara, yakni legislatif, eksekutif, dan yudikatif. Gagasan Montesquieu yang fundamental adalah setiap percampuran atau di satu tangan antara legislatif, eksekutif, dan yudikatif (seluruh atau dua dua di antara tiga) dipastikan akan menimbulkan kekuasaan atau pemerintahan yang sewenang-wenang sehingga badan (alat kelengkapan) organisasi negara harus dipisahkan satu sama lain, yakni yang satu independen terhadap yang lain. ${ }^{11}$

Peradilan satu atap di bawah kekuasaan Mahkamah Agung yang dimaksudkan untuk tercapainya kemandirian lembaga

${ }^{11}$ Lihat Ahmad Mujahidin, Peradilan Satu Atap di Indonesia (Bandung: Rafika Aditama, 2006), hlm. 6 
peradilan, hal ini dilakukan dalam upaya penegakan hukum dan keadilan yang jauh dari bayang-bayang intervensi eksekutif dan pihak lain ekstrayudisial. Penerapan sistem peradilan satu atap dalam upaya penegakan hukum yang berbasis kebenaran dan keadilan, maka sudah barang tentu melibatkan beberapa faktor, ${ }^{12}$ baik faktor internal dan faktor eksternal. ${ }^{13}$

Selain faktor-faktor tersebut, dalam rangka mewujudkan independensi lembaga peradilan tidak lain adalah kebebasan dan kemandirian lembaga peradilan dalam menjalankan fungsi dan peranannya. Sebagaimana pendapat Oemar Seno Adji14, bahwa kebebasan yang dimaksudkan adalah bersifat zakelijk fungsional 15 . Sedangkan Sudikno Mertokusumo juga memberikan makna tersendiri tentang independensi lembaga peradilan, yakni kemandirian kekuasaan kehakiman atau kebebasan hakim merupakan asas yang sifatnya universal, yang terdapat di mana saja dan kapan saja. Asas ini berarti bahwa dalam melaksanakan peradilan hakim itu pada dasarnya bebas, yaitu bebas dalam/untuk memeriksa dan mengadili perkara dan bebas dari campur tangan atau turun tangan kekuasaan ekstrayudisial. Jadi pada dasarnya dalam/untuk memeriksa dan mengadili, hakim bebas untuk menentukan sendiri cara-cara memeriksa dan mengadili. Kecuali ini pada dasarnya tidak ada pihak-pihak, baik atasan hakim yang bersangkutan maupun pihak ekstrayudisial yang boleh mencampuri jalannya sidang pengadilan. ${ }^{16}$

12 Ibid., hlm. 12

${ }_{13}$ Faktor internal adalah faktor-faktor yang berada dan terkait di dalam lingkungan lembaga peradilan, seperti faktor susunan organisasi, mekanisme kerja, hakim, kepaniteraan, dan sebagainya. Sedangkan faktor eksternal meliputi faktor-faktor yang berada di luar lembaga peradilan meliputi kekuasaan politik, dan kesadaran hukum masyarakat.

14 Mujahidin, Peradilan Satu Atap, hlm. 14

15 Kebebasan fungsional seperti diketahui mengandung larangan (verbod) menurut hukum tata negara bagi kekuasaan negara bagi kekuasaan negara lainnya untuk mengadakan intervensi dalam pemeriksaan perkara-perkara oleh hakim, dalam oordeelvorming mereka dalam menjatuhkan putusan. Dalam perundang-undangan Indonesia, ia mengalami ekstensi pengertian, dengan menyatakan bahwa ia tidak terbatas pada kebebasan campur tangan dari pihak kekuasaan negara lainnya, melainkan pada kebebasan dari paksaan, derektiva atau rekomendasi dari pihak ekstrayudisial.

16 Mujahidin, Peradilan Satu Atap, hlm. 14 
Barda Nawawi Arief memberikan ide dasar konsep kekuasaan peradilan dalam arti yang luas, adalah kekuasaan negara untuk menegakkan hukum dan keadilan demi terselenggaranya Negara Hukum Republik Indonesia. Dengan pengertian seperti ini, maka kekuasaan kehakiman tidak berarti hanya kekuasaan mengadili (kekuasaan menegakkan hukum di badan-badan peradilan), tetapi juga mencakup kekuasaan menegakkan hukum dalam seluruh proses penegakan hukum. ${ }^{17}$

\section{Sistem Hukum, Wewenang, dan Tugas Kekuasaan Kehakiman}

Sistem hukum peradilan di suatu negara dipengaruhi oleh sistem hukum yang dianut oleh negara tersebut. Sistem hukum dalam masyarakat bangsa-bangsa memiliki keanekaragaman sistem hukum satu sama lain ${ }^{18}$. Kita mengenal beberapa sistem hukum di dunia, yang mana sistem hukum yang berlaku dalam masyarakat bangsabangsa di dunia memiliki keragaman akar dan sistem hukum satu sama lain.

Menurut Eric L. Richard, pakar hukum global business dari Indiana University, menjelaskan bahwa sistem hukum yang utama di dunia (the world's major legal systems) ${ }^{19}$ meliputi: (1) Civil law yaitu suatu sistem hukum sipil yang berdasarkan pada code sipil yang sudah terkodifikasi. Hukum memperoleh kekuatan mengikat karena diwujudkan dalam bentuk undang-undang, yang disusun secara sistematis dan lengkap dalam bentuk kodifikasi atau konspilasi. Kodifikasi menurut sitem hukum Eropa kontinental merupakan sesuatu yang sangat penting untuk mewujudkan kepastian hukum. Sistem hukum ini berakar dari Hukum Romawi (Roman Law) yang dipraktikkan oleh negara-negara Eropa kontinental, termasuk juga diterapkan pada negara-negara jajahannya; (2) Common law yaitu suatu sistem hukum yang berdasarkan custom atau kebiasaan berdasarkan preseden atau judge made law. Dalam sistem hukum ini, hakim di pengadilan dapat menggunakan prinsip membuat hukum

${ }_{17}$ Ibid

18 J. Hendy Tedjonagoro, “Kekuasaan Kehakiman Yang Merdeka (The Independence of the Judiciary) dan Pelaksanaan Kekuasaan Kehakiman Menurut Undang-Undang Dasar serta Perundang-Undangan Negara Republik Indonesia", Yuridika, Vol. 19 No. 4 (Juli 2004), hlm.264

${ }_{19}$ Muchsin, Ikhtisar Hukum Indonesia, hlm. 24. 
sendiri (judge made law) dengan melihat kasus-kasus sebelumnya yang pernah terjadi. Undang-undang hanya mengatur pokok-pokoknya saja, yang diutamakan adalah kebiasaan dan hukum adat masyarakat setempat. Sistem hukum common law ini dipraktikkan di Anglo Saxon seperti Inggris dan Amerika; (3) Islamic law suatu sistem hukum yang berdasarkan syarî'ah Islâm yaitu norma-norma dan prinsip-prinsip hukum yang secara langsung bersumber pada al-Qur'ân dan alHadîts yang mempunyai sifat tetap dan tidak berubah. Dan fiqh yaitu norma-norma hukum yang merupakan hasil pemikiran manusia (fuqahâ) apabila norma-norma dan prinsip-prinsip yang ada dalam alQur'ân dan al-ㅌadîts hanya menyebutkan pokok-pokoknya saja, sedangkan sifatnya dapat berubah-ubah menyesuaikan dengan tempat dan waktu, serta case by case; (4) Socialist law yaitu suatu sistem hukum yang dipraktikkan di negara-negara sosialis; (5) SubSaharan Africa law yaitu suatu sistem hukum yang dipraktikkan di negara Afrika yang berada di sebelah selatan Gunung Sahara; dan (6) Far East Law yaitu sistem hukum timur jauh merupakan sistem hukum yang kompleks berupa perpaduan antara sistem hukum civil law, common law dan Islamic law sebagai basis fundamental masyarakat.

Sedangkan sistem hukum nasional kita terbentuk atau dipengaruhi oleh tiga pilar sistem hukum yaitu sistem hukum Barat, sistem hukum adat dan sistem hukum Islam. ${ }^{20}$ Sistem hukum Barat merupakan warisan penjajah kolonial Belanda yang mempunyai sifat individualistik, perjalanan hukum di Indonesia tidak terlepas dari sejarah bangsa Indonesia sendiri yang mengalami penjajahan dari bangsa Belanda. Dengan penjajahan tersebut sangat berpengaruh pada sistem hukum nasional kita. Sedangkan sistem hukum adat bersumber kepada peraturan-peraturan hukum tidak tertulis yang tumbuh berkembang dan dipertahankan dengan kesadaran hukum masyarakatnya.

Teori Eksistensi adalah teori yang menjelaskan bahwa ada hukum Islam dalam hukum nasional Indonesia. Menurut teori ini, keberadaan hukum Islam dalam tata hukum nasional menjadi suatu kenyataan yang tidak dapat dipungkiri keberadaannya. Bahkan merupakan bahan utama hukum nasional.

${ }^{20} \mathrm{Ibid}, \mathrm{hlm} .25$. 
Dalam Undang-undang Nomor 4 Tahun 2004 tentang kekuasaan kehakiman, pasal 2 menyebutkan bahwa penyelenggaraan kekuasaan kehakiman dilakukan oleh Mahkamah Agung dan badan peradilan yang berada di bawahnya dalam lingkungan Peradilan Umum, lingkungan Peradilan Agama, lingkungan Peradilan Militer, lingkungan Peradilan Tata Usaha Negara dan oleh sebuah Mahkamah Konstitusi. Namun dalam prakteknya ada lembaga peradilan khusus yaitu Peradilan Anak, Peradilan Niaga, Peradilan Hak Asasi Manusia, Peradilan Tindak Pidana Korupsi (TIPIKOR) yang berada dalam lingkungan Peradilan Umum serta Peradilan Pajak yang berada dalam lingkungan Peradilan Tata Usaha Negara

Undang-undang No. 4 Tahun 2004 merupakan undangundang baru yang menggantikan landasan berpikir dari kekuasaan kehakiman di Indonesia, adalah: (1) Kekuasaan kehakiman dilakukan oleh sebuah Mahkaman Agung dan badan peradilan yang berada di bawahnya, yaitu Peradilan Umum, Peradilan Agama, Peradilan Militer, Peradilan Tata Usaha Negara dan oleh Mahkaman Konstitusi; (2) Prinsip penting negara hukum adalah adanya jaminan penyelenggaraan kekuasaan kehakiman yang merdeka, bebas dari pengaruh kekuasaan lainnya untuk menyelenggarakan peradilan guna penegakan hukum dan keadilan; (3) Segala urusan mengenai peradilan yang mengangkut teknis yudisial dan organisasi, administrasi serta finansial berada di satu atap di bawah kekuasaan Mahkamah Agung; (4) Pembinaan badan peradilan (Umum, Agama, Militer dan Tata Usaha Negara) berada di bawah Mahkamah Agung. Mengingat sejarah perkembangan peradilan agama yang spesifik, maka pembinaan badan pengadilan agama dilakukan dengan memperhatikan pendapat Menteri Agama dan Majelis Ulama Indonesia; (5) Adanya Komisi Yudisial yang bersifat mandiri berwenang mengusulkan pengangkatan Hakim Agung, mempunyai wewenang lain dalam rangka menjaga dan menegakkan kehormatan, keluhuran martabat serta perilaku hakim. ${ }^{21}$

Dalam pelaksanaannya lembaga peradilan di bawah Mahkamah Agung dilaksanakan oleh empat lembaga peradilan, yaitu:

1. Peradilan Umum (General Court)

21 Tedjonagoro, “Kekuasaan Kehakiman yang Merdeka”, hlm. 274. 
Keberadaan peradilan umum selain diatur dalam pasal 2 UU No. 4 Tahun 2004 secara khusus telah diatur dalam UU No. 2 Tahun 1986 yang selanjutnya telah mengalami perubahan dengan UU No. 8 Tahun 2004. Peradilan umum adalah salah satu pelaksana kekuasaan kehakiman bagi rakyat pencari keadilan pada umumnya (pasal 2 UU No. 2 Tahun 1986), yang dimaksud dengan rakyat pencari keadilan ialah setiap orang Warga Negara Indonesia atau penduduk mencari keadilan pada pengadilan di Indonesia (vide penjelasan pasal 2). ${ }^{22}$

Secara hierarkhi lingkungan peradilan umum terdiri dari pengadilan negeri sebagai pengadilan tingkat pertama, pengadilan tinggi sebagai pengadilan tingkat banding dan berpuncak pada Mahkamah Agung.

Dalam pasal 8 UU No. 2 Tahun 1986 menyebutkan bahwa perkara-perkara yang dapat dilakukan pemeriksaan/diadili oleh Pengadilan Negeri adalah perkara pidana dan perdata serta di lingkungan peradilan umum dapat dilakukan pengkhususan pengadilan (spesialisasi/diferensial) yaitu pengadilan anak, pengadilan niaga, pengadilan hak asasi manusia, pengadilan tindak pidana korupsi (Tipikor).

Pada pengadilan tingkat pertama yang pelaksanaannya dilakukan oleh pengadilan negeri tugas dan wewenangnya adalah memeriksa, memutus serta menyelesaikan perkara pidana dan perdata yang diajukan pada tingkat pertama (pasal 50 UU No. 2 Tahun 1986). Selain itu berdasarkan pada ketentuan pasal 52 ayat (2) UU No. 2 Tahun 1986 pengadilan juga diberi tugas dan kewenangan untuk memberikan keterangan, pertimbangan dan nasehat tentang hukum kepada instansi pemerintah menyangkut hal yang tidak ada hubungannya dengan perkara yang sedang diperiksa pengadilan.

2. Peradilan Agama (Religious Court)

Peradilan Agama diatur dengan Undang-Undang No. 7 Tahun 1989 Jo. UU No. 3 Tahun 2006. Peradilan agama adalah peradilan bagi orang-orang yang beragama Islam megenai perkara-perkara perkawinan, waris, wasiat, hibah, wakaf, zakat,

22 Ibid. 
infaq, shadaqoh dan ekonomi syarî̀ah (Pasal 49 UU No. 3 Tahun 2006).

3. Peradilan Tata Usaha Negara (Administrative Court)

Peradilan Tata Usaha Negara diatur dengan UU No. 5 Tahun 1986 Jo. UU No. 9 Tahun 2004. Tujuan diadakannya peradilan tata usaha negara adalah melindungi warga masyarakat dari tindakan sewenang-wenang pejabat/aparatur pemerintah dalam kerangka pembinaan, penyempurnaan dan penertiban aparatur pemerintah agar dalam tugas-tugasnya selalu berdasarkan ketentuan perundang-undangan yang berlaku. Peradilan Tata Usaha Negara mempunyai tugas dan wewenang untuk memeriksa dan memutus sengketa tata usaha negara, maksudnya sengketa yang timbul dalam bidang tata usaha negara antara orang atau badan hukum perdata dengan badan atau pejabat tata usaha negara baik di pusat atau di daerah, termasuk sengketa kepegawaian berdasarkan peraturan perundang-undangan yang berlaku.

Putusan dari PTUN adalah putusan yang bersifat kongkrit, individual dan final yang menimbulkan akibat hukum bagi seseorang atau badan hukum perdata. Di bawah lingkungan Peradilan Tata Usaha Negara ada peradilan pajak yang diatur berdasarkan UU No. 14 Tahun 2002 yang menggantikan UU No. 17 Tahun 1997 tentang Badan Penyelesaian Sengketa Pajak. Sengketa pajak adalah sengketa yang timbul dalam bidang perpajakan antara wajib pajak atau penanggung pajak dengan pejabat yang berwenang. Pengadilan pajak sebagai pengadilan tingkat pertama dan terakhir namun dapat dimungkinkan untuk diajukan peninjauan kembali ke Mahkamah Agung.

4. Peradilan Militer (Military Court/Martial Court)

Peradilan Militer diatur dalam UU No. 31 Tahun 1997. Sebagai salah satu pilar kekuasaan kehakiman, Peradilan Militer merupakan konsekwensi logis adanya status subyek tindak pidana seorang militer, maka Peradilan Militer hanya diperuntukkan bagi militer.

Bilamana terjadi kasus pidana militer maka berlaku hukum pidana militer yang diatur dalam Kitab Undang-Undang Hukum Pidana Militer (KUHPM) sebagai hukum materiil, sedangkan hukum formilnya yang berlaku adalah Hukum Acara 
Pidana Militer. Kekuasaan kehakiman di lingkungan Peradilan Militer dilaksanakan oleh: (a) Pengadilan Militer sebagai Pengadilan Tingkat Pertama untuk perkara pidana yang dilakukan oleh anggota TNI/ABRI atau yang disamakan; (b) Pengadilan Militer Tinggi berwenang untuk perkara pidana militer, dan sebagai pengadilan tingkat pertama untuk perkara sengketa Tata Usaha Angkatan Bersenjata; (c) Pengadilan Militer Utama sebagai pengadilan tingkat banding untuk perkara sengketa tata usaha angkatan bersenjata (d) Pengadilan militer pertempuran sebagai pengadilan tingkat pertama untuk perkara pidana yang dilakukan anggota TNI/ABRI atau yang dipersamakan dalam pertempuran.

Kekuasaan kehakiman di lingkungan peradilan Militer berpuncak pada Mahkamah Agung sebagai pengadilan negara tertinggi ${ }^{23}$. Setelah berlakunya UU No. 4 Tahun 2004 hanya UU No. 31 Tahun 1997 tentang Peradilan Militer yang belum mengalami perubahan dan penyesuaian.

\section{Kekuasaan Kehakiman yang Merdeka (the independence of the judiciary)}

Pengertian Kekuasaan kehakiman mencakup arti kekuasaan kehakiman yang bebas, berwibawa, dan bertanggung jawab menurut UUD 1945 yang bersumber pada dasar falsafah negara Pancasila. Kekuasaan kehakiman merupakan salah satu unsur pokok (soko guru) negara hukum yang bersumber pada cita hukum (rechts idee). ${ }^{\mathbf{2 4}}$ Menurut ketentuan Pasal 24 ayat (1) dan (2) UUD 1945, menyebutkan: (1) Kekuasaan kehakiman merupakan kekuasaan yang merdeka untuk menyelenggarakan peradilan guna menegakkan hukum dan keadilan (disahkan pada amandemen ketiga); (2) Kekuasaan kehakiman dilakukan oleh sebuah Mahkamah Agung dan badan peradilan yang berada di bawahnya dalam lingkungan peradilan umum, lingkungan peradilan agama, lingkungan peradilan militer,

23 Ibid.

${ }^{24} \mathrm{Ibid}$ hlm. 264. Rechts idee mengandung unsur-unsur filosofis: (a) Tata hukum (rechtsorde) yang penjabarannya dalam bentuk "wet" (undang-undang); b. Rechts ada dua arti yaitu: Rechts in objectieve zin (hukum) dan Rechts in subjectieve zin (hak) 
lingkungan peradilan tata usaha negara, dan oleh sebuah Mahkamah Konstitusi (disahkan pada amandemen ketiga).

Begitu pula dipertegas dalam Pasal 1 UU Nomor 4 Tahun 2004 bahwa "kekuasaan kehakiman adalah kekuasaan Negara yang merdeka untuk menyelenggarakan peradilan guna menegakkan hukum dan keadilan berdasarkan Pancasila demi terselenggaranya Negara Hukum Republik Indonesia". Maksud dari Kekuasaan kehakiman yang merdeka adalah kekuasaan kehakiman yang tidak boleh dicampuri oleh kekuasaan eksekutif dan legislatif dalam melaksanakan fungsi peradilan. Untuk itu perlu pengaturan undang-undang bagi pelaksanaan fungsi peradilan agar tidak dicampuri atau dimasuki pengaruh kekuasaan lain demi kepentingan/perlindungan hak-hak terdakwa atau pencari keadilan.

Memang sulit untuk menciptakan kekuasaan kehakiman dalam posisi independen, kalaupun ada kekuasaan kehakiman yang independen berarti peradilan menjadi suatu mekanisme yang kuat untuk mempertahankan hukum/konstitusi dan keadilan. Dari uraian ini jelas ada korelasi antara fungsi yudikatif/peradilan dan proses demokrasi di mana pembentukan dan jaminan independensi atau kebebasan kekuasaan kehakiman seharusnya diciptakan secara aktif oleh semua sarjana hukum, polisi, kejaksaan, dan penegak hukum lainnya. Independensi kekuasaan kehakiman dapat diuji melalui dua cara, yaitu (1) Ketidakberpihakan (impartiality); dan (2) Terputusnya hubungan atau relasi dengan elite politik (political insularity).

Impartialitas hakim terlihat pada gagasan bahwa para hakim akan mendasarkan putusannya pada hukum dan fakta-fakta di persidangan bukan atas dasar keterkaitan dengan salah satu pihak yang berperkara. Impartialitas hakim bukan sesuatu yang mudah dideteksi di mana hal itu bisa dilacak dari tingkah lakunya selama menjadi hakim dalam kaitannya dengan perkara tersebut. Impartialitas proses peradilan hanya dapat dilakukan jika hakim dapat melepaskan diri dari konflik kepentingan atau collegialitas dengan pihak yang berperkara karena itu hakim harus mengundurkan diri dari proses persidangan jika ada potensi impartialitas. Dalam Sistem hukum Indonesia hakim harus mengundurkan diri jika memiliki hubungan darah atau semenda dengan salah satu pihak yang berperkara di pengadilan. 
Pemutusan relasi dengan dunia politik penting bagi para hakim agar tidak menjadi alat politik dari satu partai politik. Montesqiueu melihat independensi atau peradilan yang bebas dalam hubungan bahwa peradilan merupakan mulut undang-undang sehingga putusan hakim merupakan putusan hukum bukan putusan politik. Karena itu seorang hakim harus tidak memihak dalam proses peradilan dan putus hubungan dengan dunia politik. ${ }^{25}$

\section{Penutup}

Banyak aturan yang memberikan wadah dan pembatasan terhadap gerak dan kewenangan lembaga peradilan. Namun itu semua tidak akan berarti apa pun bilamana masing-masing badan atau lembaga masih selalu mempunyai kepentingan (pribadi atau politis) satu dengan yang lain. Banyak kasus di Indonesia yang mencerminkan turut campurnya lembaga eksekutif atau ekstrayudisial mulai dari proses sampai putusan peradilan. Padahal peraturan perundang-undangan memberikan asas kemandirian dan kemerdekaan di lembaga yudikatif. Peranan dari semua pihak sangatlah penting dalam mencipkatan penegakkan kemandirian kekuasaan kehakiman.

Dengan penerapan sistem satu atap tersebut marilah kita ciptakan prasangka baik atas penegakan hukum di Indonesia terhadap pelaksana badan/lembaga yang secara de jure telah menjadi amanat dari UUD 1945. Kita junjung tinggi tugas dan wewenangnya sesuai dengan dasar hukum yang telah ditetapkan. Lebih dari itu, jangan membuat masyarakat lebih resah dengan perseteruan yang terjadi antar lembaga peradilan sehingga kepercayaan masyarakat akan dunia peradilan menjadi pulih. Wallâh a'lam bi al-shawab.

\section{Daftar Pustaka}

Abdurrahman, H. Kekuasaan Kehakiman di Indonesia Dalam Era Reformasi. Orasi ilmiah pada acara Reuni dan Dies Natalis Sekolah Tinggi Ilmu Hukum Sultan Adam (STIHSA), Banjarmasin, 28 April 2005,

25 Tedjonagoro, Kekuasaan Kehakiman yang Merdeka, hlm. 269. 
Umi Supraptiningsih

Darmodiharjo, Darji. Sumber Dari Segala Sumber Hukum Di Indonesia. Malang: Pidato Pengukuhan yang diucapkan pada penerimaan jabatan Guru Besar Luar Biasa dalam mata kuliah filsafat hukum pada Fakultas Hukum dan Pengetahuan Masyarakat Universitas Brawijaya, 1976.

Daliyo. Pengantar Ilmu Hukum (Buku Panduan Mahasiswa). Jakarta: Prenhallindo, 2001.

Fauzan, Achmad. Perundang-undangan Lengkap tentang Peradilan Umum, Peradilan Khusus dan Mahkamah Konstitusi. Jakarta: Prenada Media, 2005.

Tedjonagoro, J. Hendy. "Kekuasaan Kehakiman Yang Merdeka (The Independence of the Judiciary) Dan Pelaksanaan Kekuasaan Kehakiman Menurut Undang-Undang Dasar Serta Perundang-Undangan Negara Republik Indonesia", Yuridika, Vol. 19 No. 4 (Juli 2004)

Kansil, CST. Pengantar Ilmu Hukum Dan Tata Hukum Indonesia. Jakarta: PN. Balai Pustaka, 1984.

Muchsin, H. Ikhtisar Hukum Indonesia. Jakarta: Iblam, 2005.

Mujahidin, Ahmad. Peradilan Satu Atap di Indonesia. Bandung: Refika Aditama, 2006.

Saleh, K. Wantjik. Kehakiman dan Peradilan. Jakarta: Ghalia Indonesia, 1977.

Wisnubroto, Al. Hakim dan Peradilan di Indonesia - dalam Beberapa Aspek Kajian. Yogyakarta: Penerbit Universitas Atma Jaya, 1997. 